\title{
RESUMOS / ABSTRACTS / RESUMES
}

\section{Marcelo Jacques de MORAES}

\author{
PODE-SE COMER UM FIGO DE PALAVRAS?
}

UMA QUESTÃO (ANTROPOFÁGICA?) COM A FRANCIS PONGE

Ao preparar a tradução brasileira de Comment une figue de paroles et pourquoi, do poeta francês Francis Ponge, hesito um pouco em relação ao título. Se o traduzo palavra por palavra (literalmente?), tenho "Como um figo de palavras e porquê". Ora, se a palavra "como" é, de fato, aquela que, em português, equivale ao advérbio comment do ponto de vista da etimologia, ela é também a primeira pessoa do verbo "comer" — o que não é absolutamente o caso em francês. O título teria, portanto, em português, ao mesmo tempo, e de maneira indecidível, dois sentidos: "De que maneira um figo de palavras e porquê" e "Eu como um figo de palavras e porquê". Essa homonímia acidental - uma vez que não é o efeito de uma genealogia interna à língua portuguesa - impõe uma oscilação de sentido que me parece, entretanto, interessante, na medida em que ela não é sem relação com o poema: neste, o figo de palavras se faz de fato devorar, ainda que deixe um resto "irredutível", seu "pequeno botão de desmame", que, tal como uma letra estrangeira, se faz mascar e remascar infinitamente. Partirei, portanto, dessa tradução "luciferina" - e que nos permite, talvez, dizer que não pode haver tradução "literal" — para discutir a dimensão performativa da poesia de (em) Ponge em sua relação com o problema da literalidade.

\section{PEUT-ON MANGER UNE FIGUE DE PAROLES?}

UNE QUESTION (ANTHROPOPHAGIQUE?) AVEC/ A FRANCIS PONGE En préparant la traduction brésilienne de Comment une figue de paroles et pourquoi, j'hésite un peu à propos du titre. Si je le traduis mot à mot (littéralement?), j'ai «Como um figo de palavras e porquê». Or, si «como» est en effet le mot qui, en portugais, équivaut à «comment» du point de vue de l'étymologie, c'est aussi la première personne du verbe «comer», 
«manger». Le titre en portugais signifie donc à la fois «Comment une figue de paroles et pourquoi» et «Je mange une figue de paroles et pourquoi». Cette homonymie accidentelle - puisqu'elle n'est pas l'effet d'une généalogie interne à la langue - pose une oscillation de sens qui me semble pourtant intéressante dans la mesure où elle n'est pas sans rapport avec le poème : dans celui-ci la figue de parole se fait vraiment dévorer, même si elle laisse aussi un reste «irréductible», son «petit bouton de sevrage», qui, tel une lettre étrangère, d'ailleurs, «nous tient tête» et, inassimilable, se fait mâcher et remâcher infiniment. Je partirai donc de cette traduction «luciférine» (Haroldo de Campos) - et qui nous permet peut-être de dire qu'il n'y a pas de traduction «littérale» - pour discuter de la dimension performative de la poésie de (chez) Ponge dans son rapport au problème de la littéralité.

\section{Alexandre NODARI}

\section{EU, PRONOME OBLÍQUO}

Por meio de uma leitura indireta (oblíqua) de três poemas de André Vallias, pretendemos, neste micro-ensaio, refletir sobre o estatuto da interlocução e da tradução, concebendo-as como operações vitais de composição de mundos. Tomando a troca posicional da posição subjetiva e a equivocidade dela resultante como pontos de partida de toda relação com a alteridade, buscamos compreender a interlocução e a tradução como procedimentos que implicam a forma oblíqua como a primeira declinação do "eu".

\section{I, OBJECT PRONOUN}

Through an indirect reading of three poems by André Vallias, we aim, in this micro-essay, to reflect on the status of interlocution and translation, perceiving both as vital operations in the building of worlds. By establishing a shift from subject to object and its resulting equivocity as the starting points of any relationship with an otherness, we seek to understand interlocution and translation as procedures which result in the object form being the first declension of "I". 


\title{
Maria Angélica DEÂNGELI
}

\author{
UM LANCE DE TRADUÇÃO: SOBRE A PASSAGEM DAS LÍNGUAS EM \\ ASSIA DJEBAR
}

Este texto discute a problemática da escrita de língua francesa na literatura magrebina contemporânea, mais precisamente na obra da escritora argelina Assia Djebar. A reavaliação feita por Djebar do papel da língua francesa no campo cultural argelino representa uma mudança significativa. Tal literatura não somente supõe uma nova relação no lugar do conflito secular entre a França e a Argélia, mas também se concebe como uma política de passagem pelo outro. Dessa forma, este trabalho busca, ainda, interrogar em que sentido a escrita na língua do outro constitui uma tarefa de tradução.

\section{LE COUP DE LA TRADUCTION: SUR LE PASSAGE DES LANGUES CHEZ ASSIA DJEBAR}

Ce texte discute la problématique de l'écriture d'expression française dans la littérature maghrébine contemporaine, plus précisément à partir de l'oeuvre de l'écrivain algérienne Assia Djebar. La réévaluation faite par Djebar du rôle de la langue française dans le champ culturel algérien représente un changement significatif. Un tel changement suppose non seulement un nouveau rapport à la place du conflit séculaire entre la France et l'Algérie, mais il atteste aussi le fait qu'une telle littérature se conçoit en tant qu'une politique de passage par l'autre. De cette façon, ce travail interroge dans quel sens l'écriture dans la langue de la langue de l'autre évoque une tâche de traduction.

\section{Helena MARTINS}

\section{VOCÊ O SOM, E EU O ECO}

"Você o som, eu o eco": assim termina o monólogo de Peter Handke em torno do qual este artigo constela, reconhecendo ali uma ficção pensante atravessada pelo motivo da tradução. Mostro que sua força singular está, em parte, nos modos poéticos como permite conjugar a tradução ao eco - e também à música, ao canto, à dança. E isso de uma forma que faz hesitar promissoramente a hierarquia entre som e eco, entre soar e ressoar. 


\section{YOU WERE THE SOUND, AND I RESOUNDED}

"You were the sound, and I resounded": thus ends the monologue by Peter Handke around which this paper revolves - a thinking fiction that responds vigorously the issue of translation. I show that the play's unique strength lies partly in the poetic ways by which translation is brought together with echo (and also with music, with song, with dance), in such a manner that the hierarchy between sound and echo is turned promisingly hesitant.

\section{Maria Clara Castellões de OLIVEIRA}

\section{PRODUÇÕES MIDIÁTICAS CONTEMPORÂNEAS E A AMPLIAÇÃO DOS LIMITES DA TRADUÇÃO}

Este trabalho apresenta uma reflexão acerca dos movimentos que, no âmbito de produções midiáticas, podem vir a ter influência sobre a prática da tradução literária. São discutidas as estratégias linguísticas encontradas nas novelas Meu Pedacinho de Chão e Geração Brasil, da Rede Globo, que se aproximam de procedimentos de tradução estrangeirizantes. Investiga-se, ainda, como legendas feitas e disponibilizadas na Internet por fãs de algumas séries de TV alargam os limites da legendagem, uma vez que se pautam em procedimentos semelhantes à tradução da letra, tal como defendeu Antoine Berman em A Tradução e a Letra ou o Albergue do Longínquo (2007 [1985]).

\section{CONTEMPORARY MEDIA PRODUCTIONS AND THE WIDENING OF TRANSLATION'S LIMITS}

This paper reflects on processes within media productions which may influence literary translation practice. We discuss language strategies found in Meu Pedacinho de Chão and Geração Brasil, soap operas by Rede Globo, which are similar to foreignizing translation procedures. We also investigate the way subtitles created and made available on the Internet by fans of certain TV series widen the limits of subtitling, as they are based on procedures similar to the "labor on the letter", advocated by Antoine Berman in A Tradução e a Letra ou o Albergue do Longínquo (2007 [1985]). 


\section{Leila Cristina de Melo DARIN}

\section{AS MÚLTIPLAS FACES DE UM ROTEIRO: O PIANO}

A presente reflexão parte do entendimento de que tradução e adaptação são processos intertextuais que implicam releituras e reescritas de um texto de partida, i.e., de um texto pré-existente. Neste artigo, abordamos o conceito de tradução e adaptação como "práticas de reescrita intertextual" Stam, 2005, p. XX). Nosso propósito é comentar aspectos das adaptações do roteiro Piano Lesson, de Jane Campion, para o livro The Piano: A Novel, por Campion e Kate Pullinger, e para o filme The Piano, dirigido por Campion, a fim de discutir as formas e recursos empregados pelas duas linguagens. THE MANIFOLD FACETS OF A SCREENPLAY: THE PIANO This discussion derives from the understanding that translation and adaptation are intertextual processes involving rereadings and rewritings of a source text (i.e., a pre-existing text). In this article, we discuss the concepts of translation and adaptation as "intertextual rewriting practices" (Stam 2005, XX). Our goal is to examine aspects of the adaptations of Jane Campion's screenplay Piano Lesson into the book The Piano: A Novel, by Campion and Kate Pullinger, and into the film The Piano, directed by Campion, in order to address the methods and resources employed in the two mediums.

\section{Márcia Atalla PIETROLUONGO}

\section{FRAGMENTOS DE UMA HISTÓRIA ÍNTIMA DA TRADUÇÃO}

Breves reflexões sobre o que poderíamos chamar de uma história íntima da tradução e sobre as possíveis repercussões das histórias pessoais que são levadas, por alguma necessidade objetiva, a ser traduzidas por um tradutor público, que se depara com a humanidade em seu caráter mais reservado e mais sigiloso através do teor dos documentos que lhe são destinados.

\section{FRAGMENTS D'UNE HISTOIRE INTIME DE LA TRADUCTION}

Brèves réflexions sur ce que l'on pourrait appeler une histoire intime de la traduction et les retentissements éventuels que les histoires privées, devant être traduites pour des raisons objectives, peuvent avoir sur le traducteur assermenté qui s'affronte dans l'exercice de sa profession à l'humanité dans 
ses aspects les plus réservés et les plus secrets à partir du contenu des documents qui lui sont donnés à traduire.

\section{Beatriz CALDAS}

MOVÊNCIA PARA O SUJEITO TRADUTOR E A LÍNGUA NACIONAL

Este artigo apresenta um trabalho de análise do discurso do prefácio de autoria de Aurélio Buarque de Holanda Ferreira para o livro de Paulo Rónai, A Tradução Vivida, de 1975. Com base no referencial teórico da Análise do Discurso, concebida por Pêcheux, e a partir do desenvolvimento de um dispositivo analítico, aponta-se para a construção de um sujeitotradutor - vinculado à imagem da língua nacional e aos processos identitários que o constituem - que é resultado da movência. Esta leva o sujeito-tradutor brasileiro de uma vinculação baseada na fidelidade religiosa a um alinhamento à língua nacional.

MOUVANCE FOR THE TRANSLATOR'S SUBJECT POSITION AND THE NATIONAL LANGUAGE

This article presents a discourse analysis of the preface by Aurélio Buarque de Holanda Ferreira written for Paulo Rónai's book, A Tradução Vivida, published in 1975. Based on Discourse Analysis, the theoretical framework designed by Pêcheux, and through the development of an analytical device, this work hopes to show that the construction of the translator's subject position--linked both to the image of the national language and to the identity processes framing him--is the result of mouvance, leading the Brazilian translator from a religious fidelity to the national language toward an affiliation with it.

\section{Teresa Dias CARNEIRO}

\section{PROPOSTA DE PARÂMETROS PARA ANÁLISE DE PARATEXTOS DE LIVROS TRADUZIDOS}

O presente artigo apresenta uma proposta de parâmetros para análise de paratextos de livros traduzidos, em especial, dos prefácios de tradutor. $\mathrm{O}$ trabalho tem como base pesquisa de doutorado realizada em 360 exemplares de obras francesas traduzidas no Brasil, de meados do século 
XX até início dos anos 2000. Por não haver uma teoria acabada sobre o assunto, a atual proposta pode ser de grande valia para pesquisadores interessados em estudar esse tipo paratextual. Também são feitas considerações sobre a posição do nome do tradutor na edição e suas implicações.

\section{PROPOSED PARAMETERS FOR THE ANALYSIS OF PARATEXTS} IN TRANSLATED BOOKS

This article proposes parameters for the analysis of paratexts in translated books, regarding in particular translator's prefaces. The work is based on a doctoral research conducted with 360 copies of French works translated in Brazil from the mid-twentieth century to the early 2000s. Since there is no comprehensive theory on the subject, this proposal may be of great value to researchers interested in studying paratexts. We also remark on the position of the translator's name on each edition and its implications.

\section{Giovana Cordeiro Campos de MELLO Priscilla Vieira de Biasi CORDEIRO}

\section{LOBATO E SUAS TRADUÇÕES DE POLLYANNA E POLLYANNA GROWS UP}

Este artigo apresenta parte da pesquisa realizada no âmbito do projeto Tradução, História e Discurso e aborda a análise de Pollyanna e Pollyanna Moça, traduções realizadas por Monteiro Lobato em 1934 e publicadas na coleção A Nova Biblioteca das Moças. O objetivo do estudo é investigar as estratégias tradutórias de Lobato em uma coleção dedicada a meninas e moças.

LOBATO AND HIS TRANSLATIONS OF POLLYANNA AND POLLYANNA GROWS UP

This paper presents part of the research developed in the frame of the project Translation, History and Discourse, and analyzes Pollyanna and Pollyanna Moça, translations carried out by Monteiro Lobato in 1934 and published in the book collection A Nova Biblioteca das Moças. This study aims to investigate Lobato's translation strategies within a collection aimed at girls and young women. 


\section{Paulo OLIVEIRA}

TRADUZIR O RADICALMENTE OUTRO

RUMO A UMA EPISTEMOLOGIA DO TRADUZIR

Discute-se aqui a filosofia da linguagem do Wittgenstein tardio, a partir dos insights epistêmicos de Da certeza e do conceito "forma(s) de vida", no que diz respeito a suas implicações para a teoria da tradução. Sugiro que questões tradicionalmente tratadas pela hermenêutica ganham novas dimensões quando abordadas por esse prisma.

TRANSLATING THE RADICAL OTHERNESS

TOWARD AN EPISTEMOLOGY OF TRANSLATING

This paper discusses the philosophy of language from the later Wittgenstein, through the epistemic insights of On Certainty and the concept of "form(s) of life", with regard to their implications for translation theory. I suggest that issues traditionally investigated by hermeneutics acquire new dimensions when approached in this light.

\section{Simone PETRY}

\section{RETRADUÇÃO E O PRINCÍPIO DA ABUNDÂNCIA}

Este ensaio apresenta o desenvolvimento do conceito de retradução no pensamento de Antoine Berman.

RETRADUCTION ET LE PRINCIPE D'ABONDANCE

Cet essai présent le développement du concept de retraduction dans la pensée d' Antoine Berman.

\section{Mauricio Mendonça CARDOZO}

\section{E PUR SI MUOVE: TEMPO E TRADUÇÃO EM MOVIMENTO}

A partir da leitura do famoso diálogo de Galileu Galilei sobre os sistemas ptolomaico e copernicano e do destaque, neste, da questão subsidiária do dogmatismo, este ensaio tem por objetivo discutir a força transformadora de nossas leituras e releituras, apontando como a mobilidade do pensamento, qual um movimento de tradução no curso do tempo, exerce impacto sobre a construção do modo como entendemos os limites de nosso próprio mundo. 


\section{E PUR SI MUOVE: TIME AND TRANSLATION ON THE MOVE}

Through the reading of the famous Galileo Galilei dialogue on Ptolemaic and Copernican systems and by highlighting the subsidiary issue of dogmatism in it, this essay aims to discuss the transforming power of readings and rereadings. It hopes to draw attention to the way in which mobility of thought, like the movement of translation over the course of time, affects the construction of the way the limits of one's own world are understood. 